\title{
Peran Pengawasan Ketua DKM dalam Meningkatkan Kemakmuran Masjid Kubah Emas
}

\author{
Andhyka Ferdiansyah*, Irfan Sanusi ${ }^{1}$, Herman $^{2}$ \\ 1Jurusan Manajemen Dakwah, Fakultas Dakwah dan Komunikasi, UIN Sunan Gunung Djati, \\ Bandung \\ *Email : 1154030010@student.uinsgd.ac.id
}

\begin{abstract}
ABSTRAK
Tujuan dari penelitian ini yaitu untuk mengetahui standar pengawasan yang diterapkan oleh ketua DKM Masjid Dian Al-Mahri, untuk mengetahui evaluasi yang dilaksanakan oleh ketua DKM dalam memakmurkan masjid, dan untuk mengetahui perbaikan (corrective) yang dilaksanakan oleh ketua DKM Masjid Dian Al-Mahri. Penelitian ini menggunakan metode deskriptif dengan pendekatan kualitatif. Adapun teknik pengumpulan data adalah observasi, wawancara dan studi dokumentasi, dari data yang diperoleh kemudian disusun dan dianalisis untuk mengungkapkan data tersebut. Berdasarkan hasil penelitian yang dilakukan dapat disimpulkan bahwa: Pertama, standar yang digunakan oleh Ketua DKM yaitu masjid yang selalu makmur dan menjadikan masjid sebagai syiar agama Islam. Kedua, evaluasi yang dilakukan oleh Ketua DKM adalah mengadakan rapat dengan pengurus dan semua staff yang ada di Masjid Kubah Emas. Ketiga, perbaikan yang dilakukan oleh Ketua DKM yaitu memberikan motivasi, saran dan keputusan dari hasil rapat yang sudah didiskusikan oleh pengurus dan stafnya tentang perbaikan tehadap penyimpangan sebelumnya.
\end{abstract}

Kata Kunci: Pengawasan; Kemakmuran; Masjid.

\section{ABSTRACT}

The purpose of this research is to find out the supervision standards applied by the Head of DKM Mosque Dian Al-Mabri, to find out the evaluation carried out by the head of DKM in prospering the mosque, In order to know the improvements carried out by the head of DKM Mosque Dian Al-Mahri. The method used in this research is descriptive method with a qualitative approach. The method used by the writer is observation, interview and documentation study, from the data that has been obtained then compiled and analyzed to reveal the data. Based on the results of research conducted at the Golden Dome Mosque regarding the supervisory role of the DKM Chair in increasing the prosperity of the mosque, it can be concluded that: First, the standard used by the Chair of the DKM is the mosque which is always prosperous and makes the mosque the symbol of Islam. Secondly, the evaluation 
U.S. Alam, D. Solahudin, Yuliani.

conducted by the Chair of DKM is to hold a meeting with the management and all staff in the Golden Dome Mosque. Third, the improvements made by the Chair of the DKM are to provide motivation, suggestions and decisions from the results of the meeting that have been discussed by the management and staff regarding improvements to previous deviations.

Keywords: Control; Prosperity; Mosque.

\section{PENDAHULUAN}

Masjid ialah sebuah bangunan yang ada dalam kehidupan muslim. Kehadirannya merupakan bagian tak terpisahkan dari kehidupan itu sendiri, masyarakat Islam dan masjid ialah sebuah totalitas sistem yang tidak dapat berdiri sendiri-sendiri (Rifa'i \& Fakhruroji, 2005: 11). Di Negara Indonesia sendiri keberadaan masjid memberikan frame tersendiri bagi masyarakat. Kita bisa menjumpai masjid di beberapa pusat perbelanjaan, pusat perkantoran, di kampus-kampus, maupun di lembaga pemerintahan bahkan di pabrik walaupun hanya mushola. Bagi yang gemar keluar kota, masjid pun mudah di jumpai di rest area atau tempat pengisian bahan bakar kendaraan. Masjid itu tidak saja hanya menjadi tempat beribadah, tetapi masjid itu juga merupakan sebuah tempat organisasi DKM.

Masjid kubah emas ini adalah salah satu masjid yang memanfaatkan ilmu manajemen dalam pengelolaannya, yang berlokasi di Jalan Meruyung Limo Depok Jawa Barat. Di dalam pengorganisasian itu pasti memiliki pemimpin dan pemimpin itu harus mengerti bagaimana cara memimpin yang baik dan benar. Fungsi masjid yang dioptimalkan perlu keterlibatan dari beberapa pihak. Butuh jamaah dan jam'iyah. Jam'iyah mempunyai arti membutuhkan kepemimpinan, tanggungjawab dan tata kerja. Sedangkan jamaah itu mempunyai arti memakmurakan masjid secara bersama-sama. Kerja sama dalam membangun secara ideal dan sesuai dengan fungsi serta memfungsikannya untuk jamaah dan umat. Oleh karena itu suatu organisasi termasuk DKM itu perlu anggota yang luwes dalam mengelola masjid, karena buruk atau baiknya masjid itu tergantung dari baik atau tidaknya pengelola yang berada di dalamnya. Masjid Dian Al-Mahri atau biasa dikenal dengan masjid kubah emas adalah salah satu masjid yang sentral untuk beribadah. Letak masjid yang berada di tengah-tengah keramaian daerah kota Depok perlu dikelola dan dikembangkan dengan baik. Karena dalam mengelola masjid itu perlu pengurus DKM yang terpecaya dan berkualitas sehingga dapat mengoptimalkan fungsi masjid sebagai pusat ibadah, ekonomi serta pendidikan.

Dibalik masjid yang makmur pasti ada seorang pemimpin yang cakap dalam kepemimpinannya sehingga ketika ada suatu kegiatan yang mengandung unsur keagamaan, jamaah banyak yang berdatangan dari dalam kota sampai terkadang luar kota pun juga ada dan tak hanya itu sarana dan prasarana yang tersedia di masjid kubah emas ini bisa di katakan sangat baik. Tetapi setelah melakukan kunjungan beberapa kali ke Masjid Kubah Emas ini peneliti belum 
pernah bertemu secara langsung dengan ketua DKM Masjid Dian Al- Mahri ini, maka dari itu peneliti merasa tertarik untuk meneliti lebih lanjut dan akan dituangkan ke dalam bentuk skripsi yang berjudul Peran pengawasan Ketua DKM dalam Meningkatkan Kemakmuran Masjid Kubah Emas.

Hasil dari penelitian terdahulu yang membahas tentang fungsi pengawasan dalam meningkatkan kinerja BMT MUI yang berhasil diselesaikan oleh Syahid Zuljalil Muslim: yang berjudul Fungsi Pengawasan dalam Meningkatkan Kinerja Baitul Maal Wat Tanwil Umat Islam (BMT MUI) Sadang, Serang Bandung. Untuk penelitian selanjutnya yang membahas tentang peranan controlling pemimpin, berhasil diselesaikan oleh Aceng Udung: yang berjudul Peranan Controlling Pemimpin dalam Pelaksanaan Kegiatan pada Organisasi Santri ALIhsan (OSPAI) Cibiru Bandung. Perbedaan dari penelitian sebelumnya dengan penelitian yang dilakukan pada saat ini yaitu penelitian sekarang dilakukan di Masjid Kubah Emas Depok. Fokus dari penelitian saat ini lebih kepada pengawasan ketua DKM dalam meningkatkan kemakmuran masjidnya. Yang mana dalam proses pengawasan terdapat beberapa langkah yaitu standar yang ditetapkan, evaluasi dan perbaikan. Kemudian hanya membahas hal-hal yang berkorelasi dengan pengawasan dalam meningkatkan kemakmuran masjid.

Lokasi penelitian ini dilaksanakan di Masjid Dian Al-Mahri yang tempatnya berada di alamat Jalan Raya Meruyung, Limo, Kota Depok, Jawa Barat dan sebagai objek utama yang diteliti yaitu pengurus DKM. Alasan memilih tempat ini sebagai objek penelitian yaitu karena informasi yang dibutuhkan mudah didapatkan serta lokasi yang mudah di jangkau dari tempat tinggal peneliti.

Dari latar belakang masalah sebelumnya yang sudah dijelaskan, dapat dirumuskan ke dalam beberapa rumusan masalah oleh peneliti yaitu: Pertama, Bagaimana standar pengawasan yang diterapkan oleh ketua DKM Masjid Dian Al- Mahri?; kedua, Bagaimana tindakan evaluasi yang dilaksanakan ketua DKM Masjid Dian Al- Mahri untuk memakmurkan masjid?; ketiga, Bagaimana perbaikan (corrective) yang dilaksanakan oleh ketua DKM masjid Dian Al- Mahri?

Metode yang digunakan oleh peneliti adalah metode deskriptif yaitu suatu rumusan masalah yang memadu penelitian untuk mengeksplorasi atau memotret situasi sosial yang akan diteliti secara menyeluruh, luas dan mendalam (Sugiono, 2007: 209). Tujuan dalam penelitian ini adalah untuk memaparkan serta menggambarkan peran pengawasan ketua DKM dalam memakmurkan masjid.

\section{LANDASAN TEORITIS}

Manajemen merupakan alat untuk mencapai tujuan yang diinginkan. Manajemen yang baik akan memudahkan terwujudnya tujuan organisasi, anggota dan masyarakat. Dengan manajemen, daya guna dan hasil guna unsur-unsur manajemen akan dapat ditinggalkan. Adapun unsur-unsur manajemen itu terdiri 
U.S. Alam, D. Solahudin, Yuliani.

dari: man, money, methode, machines, materials, dan market, disingkat $6 \mathrm{M}$ (Hasibuan, 2011: 1).

Pengawasan bisa juga didefinisikan sebagai cara untuk menjamin agar tujuan-tujuan organisasi dan manajemen dapat tercapai, ini berkaitan dengan cara-cara membuat kegiatan-kegiatan sesuai yang sudah direncanakan. Pengertian ini menunjukkan bahwa adanya hubungan yang sangat erat antara perencanaan dengan pengawasan, sehingga dasarnya atau langkah awal proses pengawasan yaitu juga langkah perencanaan, penetapan tujuan standar atau apa saja yang berkaitan dengan sasaran, tujuan dan lain-lain (Ismail, 2010: 62). Pengawasan bisa juga didefinisikan sebagai cara untuk menjamin agar tujuan-tujuan organisasi dan manajemen dapat tercapai, ini berkaitan dengan cara-cara membuat kegiatan-kegiatan sesuai yang sudah direncanakan. Pengertian ini menunjukkan bahwa adanya hubungan yang sangat erat antara perencanaan dengan pengawasan, sehingga dasarnya atau langkah awal proses pengawasan yaitu juga langkah perencanaan, penetapan tujuan standar atau apa saja yang berkaitan dengan sasaran, tujuan dan lain-lain. Tujuan utama dari fungsi pengawasan yaitu, supaya pelaksanaan kegiatan itu dapat sesuai dengan standar yang sudah ditetapkan, tetapi jika berbicara lebih lanjut, maka pengawasan itu mempunyai tujuan sebagai: Pertama, agar bisa mengetahui apakah dalam pelaksanaan kegiatan mengalami kesusahan-kesusahan yang berarti. Kedua, agar dapat mengukur apakah pekasanaan kegiatan tersebut itu efesien. Ketiga, untuk mengetahui sumber kesalahan jikalau terjadi penyimpangan dalam pelaksanaan. Keempat, untuk mencari solusi, supaya pelaksanaan bisa berjalan dengan standar yang sudah ditetapkan (Syamsi, 1994: 148).

Masjid diambil dari bahasa Arab yang asal katanya yaitu sajada (fi'il madhi) kemudian berubah bentuk menjadi masjidun (isim makan) mengikuti dari tasrif tsulatsi mujarod bab dua (sajada-yasjidu) yang mempunyai arti tempat sujud. Sedangkan masjid menurut istilah yaitu bangunan khusus yang dibangun hanya untuk tempat beribadah kepada Allah SW'T. mau itu ibadah salat atau kegiatankegiatan sosial yang mempunyai tujuan untuk mengembangkan syariat Islam (Alkaf, 1990: 440). Masjid sebagai salah satu pemenuh kebutuhan spiritual sebenarnya bukan hanya berfungsi sebagai tempat salat saja, tetapi juga merupakan media dakwah yang sangat penting, menjelaskan bahwa fungsi masjid adalah sebagai tempat yang di dalamnya banyak disebut nama Allah (tempat berdzikir), tempat beritikaf, tempat beribadah (salat), tempat pertemuan Islam untuk membicarakan urusan hidup dan perjuangan (Hadhiri, 1996: 72).

Dewan Keluarga Masjid atau biasa disingkat (DKM) atau biasa disebut juga Himpunan Jamaah Masjid (HJM) dapat didefinisikan sebagai suatu sistem kegiatan kerja sama dalam bentuk jamaah imamah yang dilakukan oleh dua orang muslim atau lebih yang memiliki ketertarikan dengan masjid untuk mencapai tujuan bersama yaitu memakmurkan masjid. DKM inilah yang bertugas untuk 
mengelola dan mengurus setiap kegiatan masjid bersama jamaah yang dipimpinnya, sampai adanya keseimbangan atau keharmonisan ide atau gagasan dalam menyebarkan dakwah Islam yang dapat terjaga dan ukhuwah islamiahnya dapat terbina. Disini juga harus saling mempercayai, dan saling tolong menolong juga bersifat kekeluargaan.

Struktur organisasi DKM adalah susunan unit-unit kerja yang menunjukkan hubungan antar unit, adanya pembagian kerja sekaligus keterpaduan fungsi-fungsi atau kegiatan-kegiatan yang berbeda-beda tersebut. Adanya wewenang, garis pembagian tugas, garis koordinasi dan laporan. Organisasi pada umumnya dapat digambarkan dalam bentuk sketsa yang disebut bagan organisasi (Ayub, 1996: 44).

Memakmurkan masjid secara hakiki adalah bentuk penghambaan (ibadah) kepada Allah SWT sesuai dengan urusan dan kedudukannya yang layak di masjid-masjid tersebut, banyaknya orang yang mengingat Allah SWT dan mengingatkan orang lain kepada Allah SWT, maka terpeliharanya masjid dari semua perkara dan perbuatan yang sia-sia. Semua tujuan ini tidak bisa diwujudkan oleh orang-orang yang benar-benar yakin kepada Allah SWT, hari akhir, yang senantiasa menegakkan salat dengan seluruh anggota tubuhnya, membayar zakat dan takut kepada Allah SWT, karena itulah mereka senantiasa siap sedia berjihad dengan diri dan harta mereka untuk menjaga dan memakmuran masjid. Orang-orang yang beriman seperti itu senantiasa mentaati Allah SW'T dengan hati, lisan, tangan, kaki, diri dan harta benda potensi berharaganya. Maka rancangan dan rencana yang penting dan wajib bagi mereka adalah memakmurkan masjid-masjid Allah SWT. (Ishaq, 2002: 28). Menurut Moh. E. Ayub (2005: 72-73) mengatakan masjid yang makmur adalah masjid yang berhasil tumbuh menjadi sentral dinamika umat. Sehingga masjid benarbenar berfungsi sebagai tempat ibadah dan pusat kebudayaan Islam dalam arti luas adalah tugas dan tanggungjawab seluruh umat Islam memakmurkan masjid yang mereka dirikan dalam masyarakat. Menurut Maulana (2010: 69-70) keberhasilan pengurus dalam memakmurkan masjid, baik dalam pengelolaan ibadah mahdoh maupun ibadah muamalah sosial kemasyarakatan, perlu memperhatikan minimal empat hal pokok sebagai berikut: Pertama, perlu membuat program dalam menciptakan suasana kerinduan jamaah untuk kembali ke masjid. Kedua, perlu membuat program aktivitas masjid yang sesuai dengan kebutuhan jamaah (umat). Ketiga, perlu membuat program kegiatan masjid yang berkesinambungan. Keempat, perlu membuat program untuk menjalin komunikasi yang harmonis dengan jamaah masjid (umat).

\section{HASIL DAN PEMBAHASAN}

Penelitian pada kali ini dilaksanakan di Masjid Kubah Emas Depok Jawa Barat. Di kota Depok terdapat masjid yang fenomenal yaitu masjid kubah emas, masjid 
U.S. Alam, D. Solahudin, Yuliani.

kubah emas dibangun oleh Almarhumah Hj. Dian Djuriah Maimun Al Rasyid. Beliau adalah pengusaha dari Banten yang membeli tanah di salah satu daerah depok ini sejak tahun 1996. Pada tahun 2001 masjid ini sudah mulai dibangun dan selesai pada akhir tahun 2006. Tepat pada hari Raya Idul Adha $1427 \mathrm{H}$ atau pada tanggal 31 Desember 2006 masjid ini resmi dibuka oleh Almarhumah Hj. Dian Djuriah Maimun Al Rasyid dan Drs. H. Maimun Al Rasyid untuk masyarakat umum yang dihadiri oleh jamaah kurang lebih 5.000 jamaah untuk menyaksikan peresmian masjid Dian Al Mahri. Kapasitas masjid ini dapat menampung jamaah sekitar 20.000 jamaah. Sejak saat itu masjid ini mulai dikenal banyak orang dengan nama masjid Kubah Emas, tak lupa dengan almarhumah Hj. Dian Al Mahri juga ikut dikenal banyak orang, tidak hanya di Indonesia bahkan beliau dikenal sampai ke berbagai negara karena banyak pihak yang kagum dengan kedermawanan syiarnya melalui pembangunan Masjid Kubah Emas ini sampai ke pelosok negara. Begitu juga dukungan yang besar dari $\mathrm{Hj}$. Maimun Al Rasyid kepada perkembangan dakwah Masjid Kubah Emas. (Majalah Kubah Emas Dian Al-Mahri, 2013, edisi khusus hal. 39-40).

Masjid Kubah Emas mempunyai bangunan seluas 60x120 meter atau sama dengan sekitar 8.000 meter persegi, itu semua sudah termasuk dari bangunan utama, mezamin, halaman dalam selasar luar dan dalam, ruang wudu serta ruang penitipan sepatu. Kapasitas masjid ini dapat menampung 15 ribu jamaah salat dan 20 ribu jamaah taklim. Dalam asia tenggara Masjid Kubah Emas termasuk salah satu masjid yang termegah. Interior bagian dalam masjid ini menunjukkan pilar-pilar yang berdiri kokoh serta tinggi sekali untuk menciptakan ruang yang agung. Warna ruang masjid ini didominasi oleh warna monokrom dengan dasar utama itu warna krem, yang memberikan arti bahwa ruangan tersebut hangat dan tenang. Bahan materialnya terbuat dari marmer yang di impor dari Italia dan Turki. Di tengah-tengah ruang terdapat lampu gantung besar yang materialnya itu terbuat dari kuningan belapis emas dengan berat 2,7 ton yang dikerjakan langsung oleh ahli dari Italia. Eksterior lingkungan Masjid Kubah Emas ini mempunyai desain yang menciptakan arti kesejukan dan keteduhan bagi siapapun umat Islam yang beribadah. Begitu pula taman yang mengelilingi sekitar masjid itu membentuk cluster-cluster agar membuat suasana yang tidak sama pada setiap sudut pandangnya. Dengan suasana lingkungan tropis dan desain penataan taman yang menggambarkan sebuah konsep penataan taman yang bergaya modern tak lupa dilengkapi dengan deretan pot-pot yang membentuk deretan arcade menambah suasana keagungan dari bangunan masjid tersebut. Untuk langit-langit kubah yang ada lukisannya itu bisa merubah warnanya sesuai dengan warna langit pada waktu-waktu salat, hal tersebut menggunakan teknologi tata cahaya yang sudah di program melalui komputer. Pada dasar kubah ada sebuah cincin lingkaran yang mempunyai akses dengan warna emas seolah itu menjadi batas cakrawala, dan di atasnya ada 33 jendela yang setiap jendelanya di isi 
dengan 3 nama Asma Allah SW'T yang total semuanya sebanyak 99. Di puncak langit terdapat kaligrafi yang tertulis berupa selawat dengan dasar bahan yang terbuat dari lempengan kuningan berlapis emas.

Adapun gaya dari kaligrafi yang ada di dalam masjid dan tersebar di semua ruang salat itu bergaya tsulutsy. Dasar bahan kaligrafi ini terbuat dari batu marmer hitam yang diselipkan marmer putih didalamnya yang menjadi warna dasar dengan menggunakan teknik waterjet. Untuk kaligrafi ini dikerjakan oleh seorang ahli khat yang ada di negeri ini, yang sudah pernah menuliskan "Mushaf Istiqlal" pada tahun 1994. Untuk dinding yang berada di ruang salat itu tertulis surat AlMu'minun ayat 1-11, lalu ada surat Thoha ayat 14 yang diposisikan diportal mihrab. Adapun untuk sepanjang dinding di sebelah selatan dan utara tertulis kalimat syahadat secara berulang-ulang yang memenuhi segmen fasadnya. Dan untuk diportal pintu masuk masjid di sebelah utara dan selatan tertulis sebuah doa itikaf dan untuk dipintu utama ditulis sebuah doa ketika memasuki masjid. (Beni, kontraktormasjid.com/masjid-kubah-emas-dian-al-mahri-depok/ diakses pada 21 januari 2019).

\section{Standar Pengawasan yang di Terapkan oleh Ketua DKM Masjid Kubah Emas}

Penetapan standar menurut (Syamsi, 1994: 150) adalah menetapkan standarstandar yang akan dipakai dalam pengawasan. Dalam mengukur pelaksanaan kegiatan perlu menetapkan standar yang akan digunakan. Bentuk dari uraian standar bisa berupa: tujuan, strategi, kebijaksanaan, saran, perintah, anggaran, intruksi, dan lain sebagainya. Standar juga bisa dibedakan dalam standar jumlah personil, standar kualitas, standar waktu penyelesaian, dan masih banyak lagi.

Dalam pengawasan ada beberapa tahapan yang harus dilalui yaitu salah satunya menetapkan standar atau bisa juga disebut pencapaian yang harus dicapai oleh suatu pengurus masjid. Standar Untuk menetapkan standar itu tidak bisa dilalui dengan asal-asalan tetapi butuh pertimbangan yang matang dan benar dalam menetapkan atau memutuskan standar yang akan digunakan oleh pengurus masjid. Karena dengan menetapkan standar kita dapat mengukur suatu pelaksanaan kegiatan itu berjalan dengan baik atau masih ada kekurangan. Berdasarkan hasil wawancara di atas dapat dipahami bahwa proses penetapan standar itu berawal dari ketua DKM yang menginginkan masjidnya selalu makmur dan mengembangkan syiar Islam, kemudian hal itu dimusyawarahkan dengan pengurus yang lain dan selanjutnya para pengurus membuat suatu kegiatan yang dapat menarik jamaah, lalu meminta respon kepada jamaah setelah mengikuti kegiatan yang ada di Masjid Kubah Emas agar bisa dimusyawarahkan kembali oleh pengurus serta Ketua DKM untuk penetapan standar yang akan datang.

Pada umumnya dalam pengawasan mempunyai tujuan yang dimaksudkan 
U.S. Alam, D. Solahudin, Yuliani.

untuk mengawasi jalannya suatu kegiatan agar tidak menyimpang dari penetapan standar. Oleh karena itu di dalam pengawasan melibatkan pihak-pihak yang bertanggung jawab untuk memberikan laporan kepada atasannya. Dari pernyataan di atas dapat dipahami untuk pihak yang terlibat dalam pengawasan adalah semua bidang yang terkait di Masjid Kubah Emas dari ketua DKM, pengurus serta anggota-anggota yang lainnya, mereka berhak melaporkan jika terjadi kesalahan atau penyimpangan dan sebenarnya apa yang mereka laporkan, mereka sudah melihatnya secara langsung jadi, pengawasan yang dilakukan ketua DKM dalam pengawasan menggunakan sistem kebersamaan tanpa membedabedakan antara ketua dan anggotanya.

Pada hasil wawancara sebelumnya dapat dipahami bahwa standar yang digunakan oleh Ketua DKM Masjid Kubah Emas yaitu hanya memakmurkan masjid dan mensyiarkan Islam. Makmur atau tidaknya suatu masjid dapat dilihat dari empat segi: Pertama, bangunan yang terjaga dan bersih; kedua, antusias para jamaah; ketiga, banyaknya kegiatan keagamaan; keempat, adanya kegiatan pendidikan. Memakmurkan masjid sesungguhnya itu juga termasuk syiar Islam yang besar karena dengan memakmurkan masjid banyak hal yang dapat dilakukan mulai dari berceramah tentang agama, mengadakan suatu kajian, menjadikan masjid sebagai tempatnya berkumpul orang orang Islam dan masih banyak lagi. Standar mengandung arti sebagai suatu satuan pengukuran yang dapat digunakan sebagai patokan untuk penilaian hasil-hasil. Tujuan, sasaran, kuota, dan target pelaksanaan dapat digunakan sebagai standar. Adapun bentuk standar yang lebih khusus antara lain target penjualan, anggaran, bagian pasar, margin keuntungan, keselamatan kerja dan sasaran produksi. Ada tiga bentuk standar yang umum: Pertama, standar-standar fisik; meliputi kuantitas barang atau jasa, jumlah langganan, atau kualitas produk. Kedua, standar-standar moneter; yang ditunjukkan dalam rupiah dan mencakup biaya tenaga kerja, biaya penjualan, laba kotor, pendapatan penjualan, dan sejenisnya. Ketiga, standarstandar waktu; meliputi kecepatan produksi atau batas waktu suatu pekerjaan harus diselesaikan (Handoko, 2003: 87).

\section{Tindakan Evaluasi yang Dilakukan Ketua DKM Masjid Kubah Emas untuk Memakmurkan Masjid}

Mengadakan evaluasi menurut menjelaskan bahwa menilai pelaksanaan kegiatan atau target yang sudah dicapai. Agar penilaian pelaksanaan kegiatan berlangsung dengan tepat, sangat perlu mengumpulkan data dan mencari dimana kesalahan berada. Untuk menilai dan pengumpulan data tentang hasil kerja yang aktual, dapat menggunakan cara yang biasa digunakan oleh seorang manajer yaitu wawancara dan angket, observasi pribadi. Disamping itu sumber informasi yang banyak digunakan para manajer yaitu laporan-laporan lisan (oral reports), laporan yang tertulis (written reports) serta laporan-laporan statistik (statistical reports). 
Menurut Robert L. Mathis da John Jackson tahun 2002 dalam jurnal (Syalsabila, 2017: 57) mengatakan bahwa penilaian kinerja merupakan proses mengevaluasi seberapa baik karyawan mengerjakan pekerjaan mereka ketika dibandingkan dengan satu set standar, dan kemudian mengomunikasikan informasi tersebut. Penilaian tersebut nantinya akan menjadi bahan masukan yang berarti dalam menilai kinerja yang dilakukan dan selanjutnya dapat dilakukan perbaikan, atau yang biasa disebut perbaikan yang berkelanjutan.

Evaluasi adalah hal yang penting dalam pengawasan karena dengan evaluasi sebuah organisasi dapat mengumpulkan data atau laporan untuk mengukur serta menilai suatu kegiatan atau program yang dilaksanakan telah sesuai dengan penetapan standar. Berdasarkan hasil wawancara yang dilakukan dengan bapak H. Muhammad Ilham mengenai proses evaluasi yang dilakukan ketua DKM bahwasannya dalam evaluasi ketua DKM dan pengurus mengadakan rapat evaluasi setelah melaksanakan kegiatan atau program yang telah direncanakan sebelumnya. Pada dasarnya rapat tersebut tidak hanya mengevaluasi kegiatan atau program saja akan tetapi segala aktivitas yang telah dilaksanakan baik dari segi sumber daya manusianya maupun aktivitas lainnya juga akan dibahas secara menyeluruh. Kemudian, apabila semua pengurus DKM dan staf-staf yang lain sudah berkumpul, maka pada saat itulah kegiatan evaluasi akan dimulai. Pembahasan yang akan dibahas pada rapat ini tak hanya evaluasi tentang kegiatan yang telah terlaksana akan tetapi pengurus serta staf yang akan di evaluasi dari segi kinerjanya. Evaluasi tersebut dilaksanakan sebagai barometer sejauh mana kegiatan serta kinerja para pengurus dan stafnya dapat tercapai sesuai dengan tujuan yang diharapkannya. Sehingga ketua DKM dan pengurus serta staf yang lain dapat mengetahuinya dengan melakukan evaluasi demi kemakmuran masjid ke depannya.

Waktu merupakan sesuatu yang berjalan begitu relatif. Terkadang dalam suatu kondisi waktu berjalan begitu cepat tetapi terkadang waktu terasa berjalan begitu lambat. Padahal, dalam setiap situasi kita tetap menjalani waktu satu hari yang sama, satu jam yang sama, satu menit yang sama bahkan satu detik yang sama. Biasanya yang membuat waktu terasa berbeda yaitu situasi dan perasaan yang kita alami. Dua hal tersebutlah yang membuat kita merasa waktu berjalan dengan lambat atau waktu berjalan dengan cepat. Ada satu hal yang tidak bisa kita lakukan kepada waktu yaitu tidak akan pernah bisa mengembalikan waktu dari setiap detiknya yang sudah kita lalui. Sekeras apapun kita usaha, atau sebanyak harta pun juga tidak bisa membeli waktu yang sudah dilalui. Oleh karena itu hasil dari wawancara sebelumnya bersama H. Muhammad Ilham pada 1 Juni 2019 mengenai waktu evaluasi dapat dipahami bahwasannya waktu pelaksanaan yang digunakan oleh ketua DKM untuk mengevaluasi yaitu satu hari setelah kegiatan atau program terlaksana. Karena tidak mau mengulur waktu terlalu panjang maka yang ditakutkan akan menyebabkan kelalaian didalamnya. 
U.S. Alam, D. Solahudin, Yuliani.

Pada saat rapat evaluasi ini juga memakan waktu yang tidak singkat karena dalam rapat ini membahas tentang kegiatan dan kinerja para pengurus serta stafnya. Kata evaluasi berasal dari bahasa Inggris evaluation yang berarti penilaian atau penaksiran. Evaluasi adalah proses penilaian. Penilaian ini bisa menjadi netral, positif atau negatif atau merupakan gabungan dari keduanya. Saat sesuatu di evaluasi biasanya orang yang mengevaluasi mengambil keputusan tentang nilai atau manfaatnya (Buchari, 1989: 79).

\section{Perbaikan (corrective) yang Dilaksanakan oleh Ketua DKM Masjid Kubah Emas}

Melakukan tindakan perbaikan menurut Kusnawan (2009: 171), melaksanakan perbaikan ketika apabila ada penyimpangan supaya pelaksanaan atau target yang sudah direncanakan dapat tercapai, tindakan korektif ini sangatlah dekat hubungannya dengan pengambilan keputusan agar bisa memperbaiki ketika ada masalah yang ditemukan. Tetapi, saat mengambil keputusan atau tindakan korektif itu bisa dilakukan secara sederhana, namun harus dengan pertimbangan yang sangat baik. Karena apabila salah dalam mengambil keputusan akan banyak hal yang bisa terpengaruh. Seseorang yang akan mengambil keputusan itu tidak boleh terpengaruh dengan faktor-faktor kecuali yang berhubungan dengan masalah yang sedang dihadapinya, solusi dari masalah tersebut akan diambil melalui suatu keputusan.

Setelah evaluasi langkah selajutnya yang tak kalah penting adalah tindakan perbaikan, karena dengan adanya tindakan perbaikan maka dapat memperbaiki penyimpangan-penyimpangan yang sudah terjadi. Harapan dari tindakan perbaikan agar penyimpangan yang sudah terjadi tidak terulang kembali dan sesuai dengan rencana yang sudah ditetapkan. Dengan perbaikan tidak menutup kemungkinan akan terjadi pergantian rencana, karena dengan hal itu kita dapat belajar dari penyimpangan yang sebelumnya. Peran ketua DKM dalam hal ini juga sangat penting karena untuk menentukan suatu keputusan perbaikan yang akan dilaksanakan ke depannya. Berdasarkan hasil wawancara yang dilakukan bersama bapak H. Eko Sukarno mengenai tindakan perbaikan yang dilakukan oleh ketua DKM bahwasannya dalam memperbaiki kesalahan atau kekurangan dalam suatu kegiatan biasanya ketua DKM mencari akar permasalahannya terlebih dahulu, setelah diketahui akar permasalahannya kemudian langkah selanjutnya yang dilakukan oleh ketua DKM ialah mendiskusikan kepada seluruh pengurus dan staf yang ada di masjid kubah emas untuk membicarakan rencana yang tepat untuk dilaksanakan ke depannya. Setiap pengurus dan staf diberikan kesempatan untuk memberikan masukan perihal rencana yang akan dilaksanakan ke depannya, tapi hasil diskusi itu sepenuhnya diputuskan oleh ketua DKM sebagai rencana untuk ke depannya.

Perbaikan dilakukan karena adanya suatu penyimpangan atau kekurangan 
dalam kegiatan. Karena jika tidak dilakukan perbaikan maka rencana selanjutnya juga akan menimbulkan suatu penyimpangan lagi. Pentingnya peran ketua dalam memutuskan tindakan perbaikan yang akan dilaksanakan untuk ke depannya. Apabila tidak terjadi penyimpangan bagaimana tindakan ketua dalam menanggapi hal tersebut. Berdasarkan hasil wawancara di atas dapat dijelaskan bahwasannya tindakan ketua DKM jika tidak ada penyimpangan adalah bersyukur. Lalu beliau selalu memberikan motivasi kepada pengurus dan para staf agar kinerjanya tetap stabil dan tidak melakukan penyimpangan. Bahkan terkadang ketua DKM memberikan penghargaan kepada kepala pengurus dan para staf yang kinerjanya stabil atau bahkan meningkat setiap harinya. Bila hasil analisa menunjukkan perlunya tindakan koreksi, tindakan ini harus diambil. Tindakan koreksi dapat diambil dalam berbagai bentuk yaitu: Pertama, mengubah standar mula-mula (barangkali terlalu tinggi atau terlalu rendah); kedua, mengubah pengukuran pelaksanaan (inspeksi terlalu sering frekuensinya, atau kurang, atau bahkan mengganti sistem pengukuran itu sendiri.); ketiga, mengubah cara dalam menganalisa dan menginterpretasikan penyimpanganpenyimpangan (Handoko, 2003: 83).

\section{PENUTUP}

Pengawasan menurut G.R Terry yaitu pengawasan dapat didefinisikan sebagai proses penentuan, apa yang harus dicapai yaitu standar, apa yang sedang dilakukan yaitu pelaksanaan, menilai pelaksanaan dan apabila perlu melakukan perbaikan-perbaikan, sehingga pelaksanaan sesuai dengan rencana yaitu selaras dengan standar (Hasibuan, 2006: 242).

Sesuai dengan perencanaan yang diperoleh melalui wawancara serta penelitian mengenai peran pengawasan ketua DKM dalam meningkatkan kemakmuran masjid kubah emas. Berdasarkan dari teori-teori yang sudah dijelaskan, peneliti dapat menganalisis menggunakan metode deskriptif, yang sudah dijelaskan di awal. Berdasarkan dari rumusan masalah yang ditemukan oleh peneliti mengenai peran ketua DKM dalam meningkatkan kemakmuran masjid kubah emas maka telah sampai di penghujung bab ini yang mana menjadi bagian akhir dalam penelitian yang sudah ditetapkan untuk memberikan kesimpulan dari keseluruhan pembahasan ini.

Peneliti dapat menyilmpulkan tentang penetapan standar diterapkan oleh Ketua DKM Masjid Kubah Emas yaitu hanya memakmurkan masjid dan menjadikan masjid sebagai syiar Islam. Makmur atau tidaknya suatu masjid dapat dilihat dari empat segi: Pertama, bangunan yang terjaga dan bersih; kedua, antusias para jamaah; ketiga, banyaknya kegiatan keagamaan; keempat, adanya kegiatan pendidikan. Kemudian untuk evaluasi yang dilakukan oleh ketua DKM yaitu mengadakan rapat dengan pengurus dan staf-staf yang lainnya. Adapun cara yang digunakan ketua DKM untuk mengumpulkan laporan yaitu ketika 
U.S. Alam, D. Solahudin, Yuliani.

rapat sedang berlangsung. Untuk waktu evaluasi yang dilaksanakan oleh ketua DKM yaitu sehari setelah acara selesai, dan yang terakhir mengenai perbaikan yang dilakukan oleh ketua DKM adalah dengan rapat evaluasi untuk mencari akar dari permasalahannya, setelah itu langkah selanjutnya ialah mendiskusikan dengan pengurus untuk mencari solusi guna memperbaikinya, ketika sudah menemukan solusi maka yang menetapkan keputusan adalah ketua DKM.

Adapun peneliti ingin memberi saran untuk meningkatkan kemakmuran masjid dalam segi pengawasan yang pertama, mengenai penetapan standar seharusnya ketua DKM lebih menjelaskan apa saja standar yang harus dicapai oleh para pengurus DKM karena sebelumnya tidak terlalu jelas standar apa yang ingin dicapainya. Kemudian saran untuk evaluasi dan perbaikan alangkah lebih baiknya untuk mengadakan rapat evaluasi seharusnya terjadwal seperti dua minggu sekali membahas tentang kinerja pengurus serta anggotanya dan dua minggu selanjutnya rapat evaluasi mengenai kegiatan, karena dengan begitu akan lebih efektif dan teratur.

\section{DAFTAR PUSTAKA}

Alkaf, (1990). Kamus Pelak-Pelik. Alquran, Jakarta: Penerbit Pustaka.

Ayub, E, M. (2005). Manajemen Masjid, Jakarta: Gema Insani

Buchari, Z. (1989). Manajemen dan Motivasi. Jakarta : Balai Aksara,1989

Hadhiri, C. (1996). Klasifikasi Kandungan Al-Quran. Jakarta.

Handoko, T.H. (2003). Manajemen, Cetakan Kedelapan Belas.Yogyakarta: BPFE Yogyakarta.

Hasibuan, M.S. (2006). Manajemen Dasar, Pengertian, dan Masalah.Jakarta: Bumi Aksara

Ismail, A.U. (2010). Manajemen Masjid, Bandung: Percetakan Angkasa.

Kusnawan, A. (2009). Manajemen Pelatihan Dakwah, Jakarta: Rineka Cipta.

Ishaq, N.M. (1996). Masjid Keutamaan, Hukum-bukumnya dan Adab-adabnya. Bandung: PT.Zaadul Ma'aad.

Maulany, H.R. (2010). Dabsyatnya Kekuatan Masjid. Bandung: Elkom Publisher

Rahmadini, S. (2017). Pola Pengawasan Kepala Seksi Penyelenggaraan Haji dan Umrah dalam Meningkatkan Kinerja Pegawai. Ilmu Dakwab: Academic Journal for Homiletic Studies

Rifa'i, A.B. (2005). Manajemen Masjid (Mengoptimalkan Fungsi Sosial Ekonomi Masjid). Bandung: Benang Merah Press.

Shihab, M.Q. (2000). W awasan Al-Quran, Bandung: Mizan

Syamsi, I. (1994) Organisasi \& Manajemen, Jakarta: PT RINEKA CIPTA 